\title{
Forgiveness and Christian Character:
}

Reconciliation, Exemplarism and the Shape of Moral Theology.

\author{
Professor Alan J Torrance \\ School of Divinity, \\ University of St Andrews, \\ St Andrews, Scotland, KY16 9JU \\ torrance@st-andrews.ac.uk
}

On 30th July, 2005 in Birmingham, England, Anthony Walker, a black British student of African descent, was walking his girlfriend to the busstop after a church meeting when he was subjected to an unprovoked and brutal racist attack. An ambulance arrived quickly but he was already dead, an ice axe buried deep into his skull. Anthony was a devout Christian, a youth leader at an evangelical church, 'Grace Family Church', 1 devoted to his family, extremely popular at school and an enthusiastic basketball player. ${ }^{2}$ Not long after his death, his family received his A-level exam results. They were outstanding and would have secured his ambition to pursue law at university and become a judge.

Days after his death, his distraught sister and later his mother agreed to be interviewed by the BBC. During the interviews, they insisted that they had forgiven Anthony's murderers. Their explanation was that as God had forgiven them in Jesus Christ, so they forgave Anthony's murderers. The impact of their comments on the British public was profound and likely to have been instrumental in the fact that this act of unthinkable racist

\footnotetext{
${ }^{1}$ http://www.eauk.org/current-affairs/news/mrs-walker-has-drawn-onher-christian-faith-to-find-forgiveness-for-the-two-young-men-whomurdered-her-son-anthony.cfm (accessed 25th Jan, 2017) ${ }^{2}$ https://www.theguardian.com/uk/2005/nov/30/ukcrime.race1
} 
violence in an ethnically diverse city did not escalate into violence on a wider scale.

The aim of this essay is threefold and this is reflected in its three parts. The first section considers what light such defining acts of Christian character shed on how we conceive of the nature and compass of moral theology. The second section assesses the theological warrant for acts of forgiveness of this kind. The challenge here will be to understand how forgiveness could be seen as normative or even obligatory given the counter-cultural and, indeed, counter-intuitive nature of forgiveness in these circumstances. The third section seeks to suggest how an account of the Christian recognition of the virtue of forgiveness might look. This will challenge 'immanentist' approaches to theological ethics, namely, approaches which assume that knowledge of how we ought to live our lives and the concepts this assumes are inherent within our minds.

In sum, our concern is to consider how moral theology might provide an account of the conditions under which this kind of redemptive orientation toward the perpetrators of violence might arise and be endorsed. To this end, I shall draw, in part, on important recent research by Michael Banner, Cristian Mihut, and Linda Zagzebski.

\section{Part 1. Christian character and the Christian community.}

The comments made by Anthony Walker's family suggest that their forgiveness was not indicative of any naturally 'felt' love toward racist murderers. Indeed, it would be troubling if they exhibited innate, subjective warmth towards the perpetrators of this crime. The way they articulated their commitment to forgive appears to have reflected an intentional and voluntary commitment to put aside any desire for vengeance or revenge on their part. The implication was that any subjective hostility they might feel should be displaced by a desire for the 
well-being of the evildoers. Second, what was also evident was that their love of enemy and the language used to express this was indicative of deeply engrained practices. These included a refusal to allow 'natural' subjective feelings to run their course. The character they showed and the way they articulated their convictions were indicative of a form of discipline that resulted from participation within a worshiping Christian community that lived from the remembrance of Christ's forgiving sacrifice.

So how far is the context of the formation of Christian attitudes of forgiveness relevant to the task of moral theology? And what does theology tell us about contextuality? In his Bampton Lectures, Ethics of Everyday Life, ${ }^{3}$ Michael Banner argues that moral theology is properly undertaken in and through considering the habits and life of the Christian community as it ought to be. When it comes to the ethics of forgiveness, therefore, moral theology seeks to identify and interpret the kinds of practices that best express 'the forgiving remembrance characteristic of Christianity's rites of recollection.' ${ }^{4}$ Moral theology is inseparable, therefore, from the task of social anthropology which recognizes that 'morality exists as a practice of such a kind that if the meaning, logic, sense, or significance of morality is to be fathomed, it will be fathomed by the sort of approach and manner of investigation characteristic of anthropology's ethnographic method.'5

For Banner, ethics is usually something 'rather quiet and regular' rather than something that we do 'with huge fanfare, in great debates about deep dilemmas or overriding principles.' ${ }^{6}$ He describes ethics, therefore, as

\footnotetext{
${ }^{3}$ Ethics of Everyday Life: moral theology, social anthropology, and the imagination of the human, (Oxford: Oxford University Press, 2014).

${ }^{4}$ Ibid.

5 Ibid.

${ }^{6}$ Ibid.
} 
essentially 'ordinary' citing Lambek who argues that it is 'relatively tacit, grounded in agreement rather than rule, in practice rather than knowledge or belief, and happening without calling undue attention to itself.'7 This, for Banner, explains the 'obvious and given' nature of ethics in the minds of its practitioners and the fact that, although there can be subliminal clarity as to what requires to be done, there is usually an inability to provide an 'immediate, ready, reasoned, and articulate account of their ethics when challenged.'8 Drawing a parallel with the subliminal nature of our knowledge of the rules of language, he adds, 'It is a similar inability, of course, to that of the speakers of a language who are typically less than forthcoming when asked to give an account of its grammar. For ethics-like grammar — often goes with saying.' ${ }^{9}$

In short, moral theology requires us to recognize that ethical practices reflect a mode of social participation that is sustained in and through subliminal commitment to an inherent grammar of action. Integral to the commitment informing Christian ethics, moreover, is an 'ordinary', unselfconscious orientation to the other - an orientation that responds to the needs of the other without treating the other as a means to an end, not least a religious or 'ethical' end. This is recognized, indeed, in Matthew's account of the 'righteous'. When the Son of Man commends the righteous for having given him food and drink, for having welcomed and clothed him and visited him in prison, the Son of Man is referring to the ethical practices that characterize the Kingdom. Jesus then adds, 'Then the righteous will answer him, 'Lord, when was it that we saw you hungry and gave you food, or thirsty and gave you something to drink...' (Matt $25: 37 \mathrm{ff}$ ). What is implied is that the righteous were not using the poor as

\footnotetext{
7 Michael Lambek, 'Introduction' in Michael Lambek (ed.), Ordinary Ethics: Anthropology, Language and Action (New York, Fordham University Press, 2010), 'Introduction', 2. (cited in Banner, op. cit.)

8 Ibid.

${ }^{9}$ Banner, op cit.
} 
a means of achieving some other end. In his theological commentary on Matthew, Stanley Hauerwas comments, 'Jesus provides food for those without food solely because they are hungry. Herod provides food for those who are not without food as a demonstration of his power... There is, therefore, a Christian way to feed the hungry that can be distinguished from those who feed the hungry for purposes beyond the feeding itself.'10

All this serves to suggest that if moral theology is to be concerned with the question of 'character', then it is important to avoid the assumption that moral character is developed in and through our concerning ourselves with it. None of this is to deny that Christian character, as we find it expressed in remarkable acts of forgiveness, concerns the mental and moral qualities of a person. It is ultimately to recognise, however, that the mental and moral qualities of a person are 'called forth' by the community (family and society) of which they are a part, occasioning an unselfconscious altercentricity. That is, it is necessary to recognise the role of the community in the cultivation of ethical practices and that these practices are not primarily cultivated by means of a direct act of self on self. ${ }^{11}$ Luther's reflections on his conversion make clear the self-defeating nature of a self-oriented approach. He describes himself as having gone to extreme lengths in his struggle to achieve righteousness. The more he tried, the more he realised that his attempts to improve his character were anything but character-neutral. What motivated his desire to cultivate Christian righteousness and its associated virtues fell victim to the kind of self-oriented pride that was inimical to Christian virtue. In short, as soon as one believes one is making progress one finds one has been drawn into a form of self-orientation that is in tension with that essential facet of Christian character, namely, humility.

10 Stanley Hauerwas, Matthew (Brazos Theological Commentary on the Bible), (Ada, Michigan, Brazos Press, 2007), p. 139.

11 See my essay, 'The self-relation, narcissism and the Gospel of Grace', Scottish Journal of Theology, Vol. 40, No. 4, 1987, p. 481-510. 


\section{Community and the excurvatus ex se Character of Christian}

\section{Forgiveness..}

If the desire to acquire Christian character risks generating self-negating results, do we not find ourselves on the horns of a dilemma? On the one hand, Christian character and the orientation toward enemy that is integral to it, appear to be a virtue, or collection of virtues, at which we should aim. On the other hand, how can we seek to cultivate it without introducing forms of motivation that have more in common with personal vanity in moral achievement than the love of other? Famously, Luther came to recognise that, borrowing a phrase from Augustine ${ }^{12}$, Christian conversion involves one's being delivered from self-orientation, from being turned in upon oneself ('incurvatus in se') to a concern with Christ and the other where one is turned away from oneself - excurvatus ex se.13 The former is the inversion of the telos for which God created us and constitutes a form, if not the form, of $\sin .{ }^{14}$ If the desire to achieve Christian character can become a self-oriented concern, clearly it is most likely to emerge precisely when a person refuses to concern herself with it and is drawn to live in the light of the recognition that her acceptance and acceptability lie with the grace of God. The nature of God's grace is

\footnotetext{
12 Matt Jenson, The Gravity of Sin: Augustine, Luther and Barth on homo incurvatus in se (London: T\&T Clark, 2007).

13 'And this is the reason why our theology is certain: it snatches us away from ourselves and places us outside ourselves, so that we... depend on that which is outside ourselves, that is, on the promise and truth of God, which cannot deceive.' LW 26:387 (cited by Jenson, op cit, p. 76.) 14 'Our nature, by the corruption of the first sin, [being] so deeply curved in on itself that it not only bends the best gifts of God towards itself and enjoys them (as is plain in the works-righteous and hypocrites), or rather even uses God himself in order to attain these gifts, but it also fails to realize that it so wickedly, curvedly, and viciously seeks all things, even God, for its own sake.' Mark Johnston, Saving God: Religion after Idolatry, (Princeton: Princeton University Press, 2009) p. 88. See also p. 91.
} 
such that it calls us to find our acceptability not in ourselves but in Jesus Christ's vicarious self-offering and obedience, that is, in his life lived in our place and on our behalf. This is to suggest that Christian character is formed in and through the gift of participating in Christ's life and thereby reposing by faith on what Luther described as the 'alien righteousness' that is fulfilled in Christ in our place and on our behalf. ${ }^{15}$ In this way, life lived sola gratia is a life delivered from the self-contradicting motivations or intentionalities that come into play when the achievement of Christian character becomes one's primary goal. Second, it is through calling forth a lived acknowledgment of God's grace that God, through his creative Spirit, generates within his creatures that excurvatus ex se orientation toward God and others that defines Christian character.

\section{Forgiveness as Normative and Obligatory rather than}

\section{Supererogatory.}

What we find emerging here is an account that appears to make sense of the comments made by the mother and sister of Anthony Walker. The interviews do not present their acts of forgiveness as attempts to achieve virtue or build Christian character. They are neither acts of 'strenuous heroism' of the kind critiqued by D.M. McKinnon or self-oriented attempts to cultivate moral character. For them, indeed, forgiveness is presented as obligatory and learned over time by people whose orientation to others is subliminally and focally shaped by their faith in Jesus Christ and the recognition of the forgiveness he enacts towards them. In sum, through their participation within the 'Body of Christ', forgiving practices toward their enemies are cultivated that run contrary to human nature and appear counterintuitive, therefore, in secular culture. ${ }^{16}$ Far from their

\footnotetext{
15 Martin Luther, "Two Kinds of Righteousness," Martin Luther: Selections from his Writings, Ed. John Dillenberger, (New York: Anchor Books,1961). $16 \mathrm{Cf}$, for example, Patricia Churchland's famous description of the essential attitudes that define success in the evolutionary derby - 'Boiled down to essentials, a nervous system enables the organism to succeed in
} 
being irrelevant, however, Gee and Dominique's statements became public testimony to the capacity that these practices have for redemption, reconciliation and, indeed, hope ${ }^{17}$ not only at the individual level but also at the societal level in the face of hideous evil.

To summarise, the interviews on television as also those that appeared in print suggest the following: the warrant for forgiveness was perceived in confessional terms. ${ }^{18}$ Second, forgiveness is not presented simply as an

the four F's: feeding, fleeing, fighting, and reproducing.' She adds, 'Truth, whatever that is, definitely takes the hindmost.' "Epistemology in the Age of Neuroscience" in Journal of Philosophy, LXXXIV (Oct 87), p. 548.

${ }^{17}$ Cf Desmond Tutu's famous insistence that 'there is no future without forgiveness' on which he wrote a book, No Future without Forgiveness, (New York: Doubleday, Random House, 1999).

18 Two articles appeared five months after Anthony's murder. In the first, entitled 'Anthony's family 'still forgive", published on the BBC News Channel, the reporter writes, 'The 20-year-old told BBC One's Real Story that she stood by her decision then to forgive whoever killed her brother. 'I did say I forgive and I do still stand by that because you have to. That's one of the things I was raised on and what my mum taught me.' 'I feel sorry for them because they didn't know what they were doing, they don't understand the magnitude of what they've done." http://news.bbc.co.uk/1/hi/england/merseyside/4471440.stm (accessed 25th Jan, 2017)

The second, a Christian publication, reads:

'Away from the court, Mrs Walker, with her daughter Dominique, 20, told assembled reporters, 'Do I forgive them? At the point of death Jesus said 'I forgive them because they don't know what they did'.

'I've got to forgive them. I still forgive them. My family and I still stand by what we believe: forgiveness." http://www.eauk.org/currentaffairs/news/mrs-walker-has-drawn-on-her-christian-faith-to-findforgiveness-for-the-two-young-men-who-murdered-her-son-anthony.cfm 
attitude but as a practice that requires to be learned and worked at over time. ${ }^{19}$ Third, their orientation towards the enemy and the associated formation of Christian character appears to have taken place not in isolation but through their participation within the practices of a faith community - practices that include communal worship, preaching, reflection on the Biblical witness and prayer $^{20}$, not least, praying for one's enemies as in the Lord's prayer.

The picture that emerges supports Banner's association of Christian ethics with forms of 'Christian remembering' with the attendant implications for how moral theology interprets it. The suggestion is that forgiveness is a form of life that is inseparable from the doxological practices and commitments that characterise a particular community. To interpret it aright means conceiving it as considerably more than a private, internal attitude, or state of mind, conceived on the analogy of Wittgenstein's 'beetle in a box'. ${ }^{21}$

The Incarnation and the Warrant for Human Forgiveness. ${ }^{22}$

(accessed 25th Jan, 2017)

${ }^{19}$ Cf 'A Mother's Forgiveness', BBC Learning https://www.youtube.com/watch?v=tgQyBLWFDBI (accessed 25th Jan, 2017) Dominique Walker (sister) 'It was hard for me at first to understand what forgiveness was but.... Two years on I know what it is and I practice it everyday and it is an everyday thing.' (from 6:12)

${ }^{20}$ Anthony's mother comments: 'Anthony was my prayer partner, we prayed together.' http://www.eauk.org/current-affairs/news/mrswalker-has-drawn-on-her-christian-faith-to-find-forgiveness-for-the-twoyoung-men-who-murdered-her-son-anthony.cfm

${ }^{21}$ Ludwig Wittgenstein, Philosophical Investigations (1.293), trans G.E.M. Anscombe, (Upper Saddle River, N.J.: Prentice Hall, 1999).

${ }^{22}$ For extended discussion of these issues cf Alan J. Torrance, 'The 
What defines both orthodoxy and its enactment (orthopraxis) within the Christian church is the recognition, constitutive of the new humanity, that the incarnate Son is 'God from God', 'of one being with the Father' - that is, that in Jesus Christ we see God present with us reconciling dysfunctional creatures both to Himself and to one another. If the eternal Word has indeed 'become flesh,' then this constitutes divine endorsement of how we are to understand both the divine nature and character but also the nature of God's purposes for us. As such, the incarnate Word constitutes the focal control on all our theological (as this includes moral theological) work at the most fundamental level. To seek to interpret God's purposes for the contingent order from some other foundation (or to relativise it by associating it exclusively with the supererogatory) constitutes a de facto rejection of God's decision to be known together with his purposes in this way and from this centre.

Second, to think from this centre is to recognise that the incarnation simultaneously and inseparably defines not only who God is but also what it is to be human. The very nature of the incarnation is such that we do not recognize the one without simultaneously recognizing the other. In the same moment, we are given to recognise the 'once and for all' (ephapax) event of God's Self-disclosure we are also given to recognise the Creator's defining purpose for humanity. In him, we know humanity not in some supernatural state but, rather, in its properly functional, natural state, that is, in the way human beings were born (natus) to be.

Third, the mediation of God's purposes in Jesus Christ is an irreducibly ecclesial event. That is, God reveals Himself to the community of the disciples and apostles generating what the Fathers referred to as an

Theological Grounds for Advocating Forgiveness and Reconciliation in the Sociopolitical Realm' in The Politics of Past Evil, Daniel Philpott (ed.), (Notre Dame: Notre Dame University Press, 2006), pp. 65-121. 
'ecclesial mind' (ekklesiastikon phronema ${ }^{23}$ ). Integral to the event of divine disclosure is the creation of a body of people (the 'communion of the body of Christ') defined by a new language and conceptuality. The perception of God's being and purposes is given in and through participation, by the Spirit, within the Body of Christ conceived as the inauguration of New Creation and a new humanity. What we term 'revelation', therefore, is not simply the communication of religious or moral ideas, or ethical instructions to be appropriated and accommodated within old wine skins. Rather, for Paul, John, and the author of Hebrews, the perceptions stemming from God's self-disclosure generate noetic, epistemic and semantic participation in that community the focus of which is the sole Mediator between God and humanity. As such, it is an event in and through which our understanding and perception of God and humanity, our language and thus our categories of interpretation, are transformed ('metamorphosed') and no longer 'schematized' by the secular order. ${ }^{24}$ Accordingly, God's selfcommunication requires to be understood as establishing a communion of mind conceived in terms of a second personal, I-thou relationship.

The koinonia or 'communion' that God establishes with humanity is generative, in turn, of communion at the 'horizontal' level - not only among Christians but also between Christians and non-Christians and, by this means, within the secular world itself. Paul summarises the relationship between the vertical and the horizontal lucidly:

'So if anyone is in Christ, there is a new creation: everything old has passed away; behold, everything has become new! All this is

\footnotetext{
${ }^{23}$ Eusebius, H. E. V. 28. 6, 13. Also, T.F. Torrance, Theology in Reconstruction, (Eugene, Oregon: Wipf and Stock, 1996), p. 43. 24 I am deliberately alluding here to the Greek injunctions that Paul uses in Romans 12:2, namely, 'Metamorphousthe!' (Be transformed!) and 'Me suschematizesthe (Do not be schematized by or conformed to [the secular order]).
} 
from God, who reconciled us to himself through Christ, and has given us the ministry of reconciliation; that is, in Christ God was reconciling the world to himself, not counting their trespasses against them, and entrusting the message of reconciliation to us.' 25

What this means is that the exhortation to forgive does not relate merely to the membership of a hermetically sealed church or, indeed, to the sphere of supererogation. From a Christian perspective, it expresses the only appropriate or 'properly functional' orientation toward the other.

In short, God is revealed in a reconciling act in and through which God's purposes for creation per se are defined. To this end, God inaugurates a new, reconciling humanity as part of his purposes of reconciling the world to himself. This new humanity is defined by practices and speech-acts (rhemata) characteristic of that life of communion that stems from the triune life and mission of God. ${ }^{26}$ The resulting orientation toward God and others is such that to say one loves God but hates one's sister, brother, neighbour or even enemy is to be a liar. ${ }^{27}$ The shape of this life is summarised by Paul's expression 'being true/speaking the truth in love' (aletheuontes en agape) - indicative that there is no dichotomy between orthopraxis and orthodoxy. Both constitute our response to God's gracious and purposive engagement with humanity and both express, therefore, what it is to be human in truth. Integral to this definition of humanity is Jesus' injunction that we should forgive seventy times seven, that is, unconditionally. What is clear is that the integrity of the incarnate God requires us to recognise that God would not endorse what God did

\footnotetext{
252 Cor 5: 17-19

26 John 17:7-8. 'Now they know that everything you have given me is from you; for the rhemata (words/speech-acts) that you gave to me I have given to them'... And later 'The glory that you have given me I have given them, so that they may be one, as we are one, I in them and you in me...' 271 John $4: 20$.
} 
not himself enact. The person of Jesus Christ is testimony, therefore, to the fact that God forgives seventy times seven, that is, unconditionally the incarnate Son prays from the cross that his murderers be forgiven.

This raises the question, however, whether such an interpretation of the grounds and warrant for Christian forgiveness takes sufficient account of the witness of the Jewish Scriptures. Clearly, to fail to grasp the latter can only lead to the misinterpretation of the New Testament. Consequently, although not only for this reason, we shall now turn to consider the Old Testament witness and the extent to which what we have argued so far is in continuity with the divine character and identity as it is represented in the Old Testament.

\section{Part 2. Forgiveness and the Character of God's Relationship to Humanity. 28}

I have argued that it is God's engagement with humanity in Jesus Christ that constitutes the ground and grammar of moral theology. To assess the continuity of this with the Jewish Scriptures, I shall begin by focussing on three key conceptions that characterise the essential form of God's relationship to humanity. In doing so, I shall also seek to show the detrimental impact of the misappropriation of these conceptions on how forgiveness has been understood within Western Christianity. To this end I shall draw on Cristian Mihut's highly pertinent insights into the central place of forgiveness in the theological conceptuality of the Jewish Scriptures.

${ }^{28}$ Part of this section reiterates argumentation that appears in my article, 'The Theological Grounds for Advocating Forgiveness and Reconciliation in the Sociopolitical Realm' in The Politics of Past Evil, ed Daniel Philpott, (Notre Dame: Notre Dame University Press, 2006), pp. 65-121. 


\section{a) Divine Forgiveness is Covenantal, not Contractual - the necessity of distinguishing berith from foedus}

Fundamental to the interpretation of God's relationship to humanity, both in the Jewish Scriptures and also in the New Testament, is the concept of covenant 'berith'. Although berith is used in various ways, when it is used theologically it denotes a promise binding two people or two parties to love one another unconditionally. ${ }^{29}$ It is for this reason that it has traditionally been used in the marriage service - a couple promise and covenant to love one another for better for worse, that is, unconditionally. It is precisely the unconditional nature of the covenant commitment that makes a covenant so different from a contract. The latter denotes a legal arrangement that is essentially conditional - it denotes an impersonal business deal, a conditional arrangement - 'If you complete task $\mathrm{x}$ by $\mathrm{t}^{\mathrm{n}}$, then I shall pay you $s^{n}$.

It is no less important that we also distinguish between a unilateral and a bilateral covenant. Whereas marriage is an example of a bilateral covenant (it requires the free-minded commitment of two equal parties), the covenant between God and Israel is unilateral, and not bilateral. God establishes and ratifies his covenant commitment unilaterally in advance of and thus independently of any reciprocal commitment on the part of Israel. To the extent that forgiveness is integral to God's covenant commitment

\footnotetext{
${ }^{29}$ I am drawing here on the research of James B Torrance, most specifically his articles 'Covenant and Contract, a study of the theological background of worship in seventeenth-century Scotland' Scottish Journal of Theology, Vol. 23, Issue 1 (Feb 1970), pp. 51-76 and 'The Contribution of McLeod Campbell to Scottish Theology', Scottish Journal of Theology Vol. 26 (1973), pp. 295-311. Cf Alexandra Radcliff, The Claim of Humanity in Christ: Salvation and Sanctification in the Theology of T. F. and J. B. Torrance, (Eugene, Oregon: Princeton Theological Monograph Series, Pickwick Publications, 2016) esp. chapter one: 'The Father as Covenant not Contract God: Filial over Federal.'
} 
and covenant faithfulness, forgiveness will be seen to be unilateral, that is, unconditional and unconditioned.

The failure on the part of so much Western theology (not least Federal Calvinism) to recognise the fundamental distinction between a covenantal and a contractual relationship between God and humanity has had a profoundly detrimental and distortive impact on the shape of moral theology in general and the place of forgiveness in Christian ethics in particular. Apodictic obligations that stemmed from God's unconditioned and unconditional faithfulness came to be interpreted as contractually conceived, conditions of salvation. This is made explicit in Federal Calvinism's theory of the contract of works (foedus operum) or contract of nature (foedus naturale). Even the New Covenant was conceived in contractual terms as a salvific pact ('pactum salutis'). The result was an ethic grounded in fear - fear of a God who, first, required to be conditioned into loving and forgiving the sinner and, second, who only forgave you if you happened to belong to the 'elect'. This meant that the God of the Christian faith was not a God whose orientation towards his enemies was characterised by unconditional love and forgiveness - the God who comes to an alienated humanity as Jesus Christ in the person of one who forgives 'seventy times seven' and desires, therefore, that those created to image God do likewise.

\section{b) Divine Forgiveness reflects the heart of the torah - the necessity of distinguishing torah from lex.}

The heart of the torah is its testimony to God's covenant commitment and faithfulness (hesed) toward Israel as expressed in God's deliverance of Israel from slavery. Consequently, the apodictic obligations spelled out in Exodus 20 (the 'Ten Commandments') define the nature of our response to God's covenant faithfulness - 'I am the Lord your God, who brought you out of the land of Egypt, out of the house of slavery'. Therefore, as God has been faithful to Israel so Israel is to be faithful towards God (vv. 3-11) and so 'you shall have no other gods before me...'. And, second, as God is 
faithful to the people of Israel, so they are called to be faithful to each other, that is, to all those to whom God is faithful: 'you must honour your parents, you must not kill, commit adultery, steal, lie, etc.' (vv. 12-17). In short, we are to love God and our neighbour as God first loved us and because that is the only appropriate form of response to the fact that God first loved us. When the lawyer in Luke 10:27 summarised the torah as 'You shall love the Lord your God with all your heart, and with all your soul, and with all your strength, and with all your mind; and your neighbor as yourself.' he was summarising the heart of the torah as a faithful Jew. And Jesus endorsed his summary accordingly. Human beings have been created in the image of God to image/reflect God's covenant faithfulness. The so-called 'ten commandments' spell out the concrete form of this reciprocal faithfulness.

Yet again, however, a widely influential theological distortion of this emerged in the Christian tradition. The Hebrew word torah was translated (via the Greek nomos) by the Latin lex (law). The consequence in Western scholasticism was that torah was interpreted under the pressure of Stoic conceptions of lex and, indeed, wider interpretations of 'natural law'. This resulted in the tendency of moral theologians to bracket out the whole context of covenant belonging and covenant faithfulness as it had served both to underwrite and provide warrant for the exhortations at the heart of the torah. It also meant that the obligation to forgive lost its force with the result that it came to be viewed as supererogatory rather than as reflecting what we were created to be.

\section{c) God's Forgiveness is an expression of God's Righteousness - the necessity of distinguishing tsedaqah from iustitia.}

The two misinterpretations above compounded a similar misappropriation of the concept of righteousness. In the context of the Jewish Scriptures it requires to be understood in covenantal terms as the righteousness of the God who remains true to his covenant promises. Both God's tsedaqah (righteousness) and hesed (covenant faithfulness) refer to God's 
maintaining covenant loyalty ${ }^{30}$ to Israel, his beloved child. ${ }^{31}$ Within the legal apperception of the West, however, tsedaqah (righteousness) came to be construed as iustitia (justice). This resulted in a further dramatic shift in the approach to moral theology. Whereas forgiveness should have been seen as an appropriate expression of righteousness, it was problematic to construe it as an expression of justice (iustitia). The result was the relocation of forgiveness within the realm of the supererogatory and its reinterpretation in radically contractual and conditional terms.

In sum, what amounts to three, theological mistranslations has generated a dramatic semantic/conceptual shift in Western moral theology. The effect of this has been to translate thinking about God from essentially filial and koinonial categories into legal categories - from categories that are 'second personal' in character to impersonal, 'third person' modes of interpretation.

The following diagram seeks to clarify the difference between the grounding of moral theology and the grammar of forgiveness in the three, inter-related categories in the left hand column and their appropriation and misconstrual in terms of the categories outlined in the right hand column.

$\begin{array}{llll}\text { Hebrew } & \text { Greek } & \text { Latin } \\ \text { berith (covenant) } & \rightarrow & \text { diatheke } & \text { foedus } \\ \text { (contract) } & & \end{array}$

\footnotetext{
30 Cf Deuteronomy 7:9.

${ }^{31}$ As Cristian Mihut argues, hesed does not simply denote an affective inclination. Rather, 'hesed is a stable and permanent commitment to act lovingly toward Israel.' Mihut, 'Bearing Burdens and the Character of God in the Hebrew Bible', Character: New Directions from Philosophy, Psychology, and Theology. Ed. Christian Miller, R. Michael Furr, Angela Knobel, and William Fleeson (New York: Oxford University Press, 2015), chapter 17, p. 380.
} 


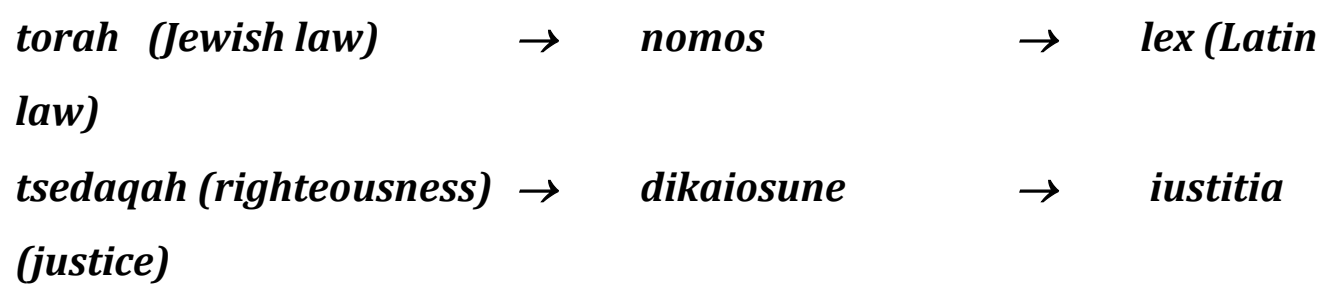

The semantic shift from the categories on the left to those on the right resulted in the displacing of the essentially filial categories at the heart of the Jewish Scriptures by the individualistic and legal categories that characterized the Latin West. The narrative of Israel's belonging to a faithful covenant God was reconceived in terms of a foreign salvific system spelling out contractual conditions of inclusion and the requirements of justice demanded by an essentially impersonal and transcendent Law-giver.

The distinction between the filial and legal here relates to Andrew Pinsent and Eleonore Stump's lament over the loss of 'second person' approaches to understanding the relationship between God and humanity. ${ }^{32}$ The key injunctions of the torah are couched in second personal terms - 'I am the Lord, your God, who brought you out of the land of Egypt...' As Pinsent has commented, a proper emphasis on the covenant relationship lends itself to the language of the second person. It is not insignificant that the great Jewish thinker, Martin Buber, so stressed the importance of appreciating both the conceptuality of covenant and that of the I-thou relationship. ${ }^{33} \mathrm{By}$ contrast, the language of contract is not the language of personal address and lends itself more readily to expression in third personal, legal terms.

\footnotetext{
32 Pinsent, A., and Stump, E. (eds.), The Second-Personal in the Philosophy of Religion. Special edition of the European Journal of the Philosophy of Religion, Vol. 5, No. 4, Winter 2013.

33 Pinsent, A. C., "Cosmic Purpose and the Question of a Personal God," European Journal for Philosophy of Religion, Vol. 5, No. 1, (March 2013), p.
} 194. 
Another consequence of the shift from the interpretation of the torah in filial, covenantal and second person terms to its appropriation in legal, contractual and third person terms was a Marcionite polarization between the 'god of the Old Testament' and the 'god of the New Testament'. One tragic effect of this was the compounding of anti-Semitic attitudes within Western Christianity not least within Lutheranism. The misconceptions here have been widely challenged in modern New Testament scholarship particularly since the emergence of E.P. Sanders' field-changing monograph on Paul and Palestinian Judaism ${ }^{34}$. More recently, Douglas Campbell's work provides a telling critique of the misconceptions inherent in the Western ordo salutis and the attendant misappropriation of the Jewish categories of covenant and torah. ${ }^{35}$

So, what is the significance of this for understanding forgiveness? First, God's commitment to Israel is covenantal and not contractual. It is, moreover, unilateral and not bilateral. Consequently, God's hesed (covenant faithfulness) toward Israel is unwavering despite Israel's unfaithfulness. Intrinsic to this, moreover, is a sustained and ongoing commitment to forgive Israel despite the fact that its iniquities are ongoing - as Cristian Mihut's research has shown, God's commitment to forgive belongs to the very essence of God's relationship to Israel.

34 E.P. Sanders, Paul and Palestinian Judaism: A Comparison of Patterns of Religion, (Minneapolis, Fortress, 1977). Martin Buber, I and Thou, (originally 1923) (New York: Simon \& Schuster, 2000) and Moses: The Revelation and the Covenant, (originally 1946), (New York, Harper, 1965). 35 Cf Douglas Campbell's insightful monograph: The Deliverance of God: An Apocalyptic Rereading of Justification in Paul (Grand Rapids, Mich.: Eerdmans, 2009). See especially Part 1. pp. 11-219. "Justification Theory, and Its Implications." Cf also, his "Covenant or Contract in the Interpretation of Paul," Participatio: Journal of the Thomas F. Torrance Theological Fellowship Supp. Vol. 3: A Tribute to James B. Torrance (2014), pp. 182-200. 
Second, the ten commandments do not articulate conditions of God's acceptance and forgiveness. Rather, they spell out the obligations that stem from God's commitment to his people - a commitment that is unconditional. (As Paul argues in Galatians 3:17, if the law adds conditions to the promised commitment God made 430 years previously, then God has broken his promise!)

Third, the Western language of justice, which has been used so widely to present a contractual account of forgiveness by making it conditional upon the fulfillment of requirements, misrepresents the language of righteousness in the Jewish Scriptures - a righteousness that denotes God's faithfulness to the covenant commitments he has made. As Mihut observes, 'hesed fixed the contours of divine agency.'36

Cristian Mihut's insightful analysis provides a telling critique of the 'classical picture of divine character' as we find it exemplified in Michael Morgan's account. ${ }^{37}$ The latter presents the biblical God as a just lawgiver whose 'normative response of God to sin is anger and retribution'38 and for whom forgiveness is presented as a supplement or 'a surplus that includes a change of attitude, a sense of goodwill, and an overcoming of the sense of being violated, humiliated, or diminished.'39

\footnotetext{
36 Mihut, op. cit,, p. 381.

37 This section draws on Cristian Mihut's analysis of forgiveness and the divine character in the Jewish Scriptures. Ibid., pp. 368-392.

38 Morgan, Michael L. 'Mercy, Repentance, and Forgiveness in Ancient Judaism.' In Ancient Forgiveness: Classical, Judaic, and Christian, in Charles Griswold and David Konstan (eds.), (Cambridge: Cambridge University Press, 2012), p. 131. Cited by Mihut, op.cit., p. 368.

39 Morgan, op.cit., p. 142.
} 
Mihut rightly repudiates the suggestion that divine forgiveness is 'subordinate to divine forensic justice.' 40 It is grounded, he argues, in God's sustained and ongoing covenant faithfulness toward Israel despite her ongoing sin, wickedness and rebellion: 'Forgiveness is not an anomaly at the outskirts of a fully integrated retributive deity. It is not chiefly the tamer of fierce justice, and not the therapy God needs to get over the sense of being violated.... Forgivingness - the settled disposition to forgive - is at the center of God's agency, and is grounded in proactive, other-directed dispositions that figure deeply in the explanation of divine action. 41

Definitive of the character of God in the Jewish Scriptures, Mihut suggests, are the dispositions articulated in the 'grace formula' of Exodus 34.42 Central to this is the 'pervasive and theologically vital metaphor of nasaawon (bearing away transgression)' which presents God paradigmatically as a healer and forgiver of his people. Three key Biblical images penetrate to the 'very kernel' of divine forgiveness. The first presents God as cancelling the debt of $\sin .{ }^{43}$ Related metaphors include God's blotting out iniquity, ${ }^{44}$ covering it (kipper) ${ }^{45}$ and bearing it away (nasa awon). ${ }^{46}$ The

40 Mihut, p. 368. Indeed, on the kind of account we see exemplified by Morgan, '(d)ivine justice has theological, normative, and motivational primacy. Forgiveness is at best a tamer of retribution.' Mihut, p. 369. 41 Mihut, p. 369.

42 Mihut takes this from Exodus 34: 6 - 7 in the translation of Everett Fox, The Five Books of Moses. (New York: Schocken Books, 1997), p. 455. Cited by Mihut, p. 372.

43 Here Mihut adds the footnote: 'This picture of forgiveness becomes much more prominent in the New Testament. See Matthew 6:12. Gary Anderson claims, for instance, 'in the New Testament the metaphor of sin as debt was ubiquitous.' (Anderson 2009: 31)' Mihut, p. 372.

44 Ps 51:9. 
second denotes a model of forgiveness whereby 'the victim countenances the offense while forgoing the pursuit of retaliatory measures.' 47 The third suggest that God's primary concern is 'healing and unburdening a broken people. $^{48}$

The distinctive content of the controlling metaphor for this (nasa-based) account of forgiveness is provided by 'two interlocking commitments: (Ci) God's commitment to set a distance between individuals/community and their sins , and (Cii) God's commitment to absorb in himself the consequences of iniquity.' 49

Both of these commitments stand in radical continuity with the whole thrust of God's covenant faithfulness to Israel - his unconditional and unconditioned filial commitment to his beloved children. ${ }^{50}$ Is this in tension with God's 'justice'? Only if we project onto the narratives interpreting God's tsedaqah a foreign conception of iustitia with its associated contractual conditions and legal requirements. When we interpret God's righteousness in the light of the theology of covenant and the obligations that stem from God's hesed, then a nasa-based account of divine forgiveness constitutes the profoundest expression of precisely how God's righteousness is to be conceived.

45 See Psalm 85: 2 - 4: 'You forgave (nasa) the iniquity of Your people; You covered all their sin. You withdrew all Your fury; You turned away from Your burning anger.' Mihut comments that here, two images of forgiveness - carrying burdens and covering iniquity - occur side by side. 46 Exodus 34:7. Cf. Mihut, pp. 370-1.

47 Mihut, p. 371.

48 Mihut, p. 372.

${ }^{49}$ Mihut, p. 382.

50 Cf. Deut 14:1, Psalm 73:15, Jeremiah 31:20. 
What emerges is the profound continuity between the conception of God's character at the heart of the Jewish Scriptures and the character of God as defined through the incarnation. What we also see is a clear parallel between the forgiveness that characterises the true imago patris and that forgiveness which characterises those who 'image' God's unconditional, covenant faithfulness. As we have seen, it is precisely such a human corresponding to God's faithfulness that the torah advocates.

\section{Part Three: Forgiveness and the Place of Moral Transformation in Christian Ethics.}

What remains to be considered are the full implications of this interpretation of the connection between God's nasa-awon forgiveness and forgiveness between human beings. The most cursory analysis of the grammar of obligation in the Pentateuch makes it clear why the indicatives of grace must be viewed as prior to the imperatives of obligation. To reverse this order, to make the imperatives of law prior to the indicatives of grace, is to convert a covenant into a contract - the obligations that stem from God's grace become the conditions of grace.

As we have seen, that has the effect of radically redefining the character of God, presenting God as a distant, impersonal 'god of justice' who requires to be conditioned into being faithful and whose forgiveness is conditional upon satisfying the requirements of justice. It is this 'classical picture of the divine character', to use Mihut's description, that underpins retributive accounts of the atonement and the perceived penal necessity of Christ's substitutionary death on the cross.

Such a move presents the nature of God's relationship to humanity in legal rather than filial terms. The effect of this is to redefine the impetus and warrant for moral transformation. In short, it has a profound impact on the moral psychology at the heart of the faith. 


\section{Divine Forgiveness as an Organ of Moral Transformation.}

Human and social transformation belong to the essence of God's mission to a hostile and dysfunctional world. Although this transformation is articulated in various ways throughout the New Testament, most significant concept used to describe this is 'metanoia'. This denotes the transformation of our orientation towards God and also towards the world - the reconciliation and reconstitution of our dysfunctional modes of thought. ${ }^{51}$ This is what Paul envisages in exhorting us to be 'metamorphosed' in order to discern the truth. ${ }^{52}$

This transformation of mind is clearly not something that can be brought about by our own abilities given that it is precisely our capacity to process reality aright that is dysfunctional and in need of redemption. 'Metanoia' denotes an act that takes place 'from above'. What it delivers, moreover, is qualitatively different from any 'optional' perspective or 'Christian worldview'. As Murray Rae argues, this is no mere duck-rabbit Gestalt switch. It doesn't simply denote a different form of 'seeing as' or perspective where both the new and the old way of interpreting reality has its own validity. It is closer, he argues, to a 'paradigm shift' through which we are delivered from an erroneous, 'alienated' processing of reality to a new, redeemed way of relating to God and others - such that it is not a valid option to return to the previous one. ${ }^{53}$ Still further, the paradigm shift to which we are referring is considerably more than the kind of paradigm shift that Kuhn describes as taking place in the sciences. The New Testament bears witness to a paradigm shift that is sui generis,

${ }^{51}$ For Paul, we are echthroi te dianoia, that is, hostile/alienated in our capacity literally 'to think through to' God's purposes). Noein (to think), is the common root of both metanoia and dianoia and the call for metanoia in the Gospels denotes the reconciliation of our dysfunctional minds.

52 Romans 12:2.

53 Murray Rae, By Faith Transformed: Kierkegaard's Vision of the Incarnation, (Oxford: Clarendon Press, 1997). 
denoting nothing less than God's redemption of our erroneous processing of reality - the shift from viewing the world kata sarka (in accordance with the flesh) to viewing it kata pneuma (in accordance with the spirit). For the author of John's Gospel, the resulting metanoia is nothing less than an event of regeneration or 'rebirth' 'from above'. To summarise, metanoia denotes a new redeemed orientation towards God and the world that is so radically discontinuous with the old that it is described in terms of the reconstitution of our identities - our being 'born again' to participate in a 'new humanity' whereby we are given 'eyes to see' and 'ears to hear' what we could not otherwise recognise or appropriate. What is relevant for our purposes here is that this metanoia involves the redemption of our orientation not only towards God but also towards our neighbours. We are given to 'see' them anew with redeemed minds in the radically new light of God's creative and reconciling love.

It is not insignificant that in the Sermon on the Plain in Luke, the context of Jesus' injunction that we love our enemies and do good to those who hate $\mathrm{us}^{54}$ is the healing of people from disease. ${ }^{55}$ The same applies to the parallel injunctions in Matthew. In the Sermon on the Mount, the context of the exhortation that we love our enemies is Jesus' curing people of disease and dysfunction - illness, demon-possession, paralysis. (Matt 4: 23-24). The clear implication is that the Kingdom of God is manifest where we are delivered from the dysfunctionality of unforgiving, unreconciling hearts and set free to love our neighbours and forgive our enemies.

\section{Metanoia as 'evangelical' and not 'legal'.}

So what are the specific means through which God effects this 'conversion' or 'repentance'? The argument of the following section is that

\footnotetext{
54 'Love your enemies, do good to those who hate you, bless those who curse you, pray for those who abuse you.' Luke 6:27-28 (N.R.S.V.). 55 Cf. Luke 6: 18-19.
} 
this redemptive dynamic is enacted in and through a process whereby alienated creatures are given to see themselves as loved and forgiven. That is, the means by which God generates this metanoia is itself inherently filial and covenantal rather than legal and contractual.

In a tradition that can be traced from John Calvin, through Thomas Boston of Simprin and John Colquhoun to F.D. Maurice, a key distinction is drawn between 'evangelical repentance' and 'legal repentance'. 'Legal repentance' suggests that the primary means of inducing metanoia are the dictates of law. On this view, it is when we are presented with the judgement and condemnation that issues from the law, that we are motivated to repent. Although legal repentance does not necessarily assume contractual categories, it can prey upon the church's desire to 'control' its adherents by presenting them with the full force and implications of divine law. In these situations, the law can function contractually: 'IF you want God to be merciful toward you, THEN you must repent and obey the law!' The consequences of such an approach and the messages it sends are far from neutral. The implication is that God does not love or forgive people unless they first deliver what is required, namely, repentance and obedience. The second point to notice is that legal repentance serves to compound (rather than challenge) selfinterest as the driving motivation in Christian ethics. For this reason, it serves to weaken rather than strengthen the love of God and neighbour and thus weakens the law, as Jesus summarises it. (Most parents take it as a given that if they treat their children in contractual ways that communicate conditional acceptance their approach is unlikely to generate respect let alone love for them as parents.) Third, the treatment of the other that stems from legal repentance is unlikely to be a love of the other for her own sake and more likely to be the expression of an egocentric self-concern - precisely what Luther recognised as the essential form of sin. Finally, fear displaces love as the motivating force in ethics - fear of divine judgement and the condemnation that the law generates. 
In sharp contrast, the kind of transformation that 'evangelical repentance' describes is profoundly different. Evangelical repentance refers to that form of metanoia that stems from recognising God's unconditional love for humanity manifest in Jesus Christ - a love that forgives despite humanity's hostility, despites its alienation and, indeed, the forms of selfinterested motivation that that alienation takes.

What is important to note is that the focus of evangelical repentance is not simply a divine orientation towards humanity characterised by sentiments of love and forgiveness. For the authors of the New Testament epistles, evangelical metanoia recognises the length to which God's love goes and the cost of our being delivered from the condemnation of our dysfunctional response to God. For Paul and the author of Hebrews, God's love for humanity finds expression in the fact that God provides the very response that God requires of us. Evangelical metanoia emerges as one recognises that the incarnate Son has provided on behalf of humanity - as its sole priest, mediator and intercessor - a vicarious Amen on behalf of an alienated humanity. Christ is not only the Sole Mediator of God's love for humanity but he is the sole Mediator of humanity's 'yes' to God. Such is God's faithfulness and love for sinners that God himself provides the response, the obedience and the properly functional acknowledgment of God's faithfulness that we are obliged to offer but fail to provide. He does this in our place and on our behalf. So what are the implications of this gift of grace for the human response? It means that the new humanity lives from the recognition that all that righteousness requires has been fulfilled from our side, in our place and on our behalf - 'the righteous requirement of the law' (Romans 8:4) and 'the righteous requirements of worship' (Hebrews 9:1) have been provided in Jesus Christ the sole priest and mediator of our response and confession. Consequently, human righteousness lies not in anything we can provide but in the vicarious faith and faithfulness of the incarnate Son. God's acceptance and 
forgiveness of a dysfunctional humanity is enacted and fulfilled objectively 'en Christo'.

Whereas, the use of law to generate 'legal repentance' throws people back upon themselves by presenting people with a message of judgement, condemnation and conditional acceptance, evangelical repentance denotes the transformation that the Gospel generates - that, as Paul so stresses, (Romans 8:1) 'there is therefore now no condemnation for those who are in Christ Jesus.'

Is this not, however, to open the door to a lax antinomianism? As the case of Anthony Walker's mother and sister appears to indicate, the perception of the extent of God's forgiveness generates a kind of discipleship and commitment that generates practices and Christian character of a kind that exceed anything that presenting people with the divine or moral law could possibly achieve. Still further, evangelical repentance of this kind generates a second-person, 'I-thou' relationship that is transformative. Susan Eastman comments: 'Paul's account in Romans of the divine action that moves persons into a new identity of self-in-relationship demonstrates genuinely second-personal qualities: it is loving, nontransactional, noncompetitive, mutual, and constitutive of personal agency. 56

Testimony to the 'evangelical' basis of repentance is not only to be found in Paul or John or Hebrews; it is also present throughout the Synoptics. The story of Zacchaeus in Luke 19 is testimony to the psychology of evangelical repentance. Luke makes it clear that Zacchaeus came to Jesus motivated not by guilt or by repentance but simply by curiosity. What Jesus does upon seeing Zacchaeus is neither to condemn him nor, indeed,

\footnotetext{
56 Susan Eastman, 'The Shadow Side of Second-Person Engagement: Sin in Paul's Letter to the Romans' in European Journal for Philosophy of Religion, Volume 5, Number 4, (Winter 2013).
} 
to remind him of the law in the hope that this might deliver him from the error of his ways. What issues from Jesus is categorical affirmation of his dignity in the presence of those who, understandably, despise him people who were frustrated, indeed, by Jesus' attitude. (v. 7). Urging Zacchaeus to hurry up, he insists he wants to come and stay and eat with him. The immediate consequence of Zacchaeus' perception of Jesus' love for him is the transformation of his orientation towards those whom he has used. Not only does he make amends (the reparation or satisfaction that legal repentance requires), but he returns what he owes several times over. In short, the core command of the torah is fulfilled in Zacchaeus' consequent love of his neighbours. A similar logic is evident in Jesus' dealings with the woman at the well and the woman caught in adultery.

Evangelical repentance is also central to the 'parable of the lost son' despite the fact that it is used to argue for the opposite. The renegade younger son breaks every facet of the torah beginning with his public dishonouring of his father wishing his father were dead - he had been committing murder in his heart. He then went on to break almost every other defining Jewish taboo culminating symbolically in his sharing meals with unclean animals. The son then determines to return home. His motivation, however, is not guilt or fear of condemnation. What motivates him is the fact that he covets his father's servants given that they are eating better than he is. Consequently, he prepares a speech designed to manipulate his father and use him still further. Rather than presenting the son with the full force of the law, the father runs to embrace him without seeking evidence of contrition or repentance. What is significant is that, in the arms of his father, the contractual element in the son's pre-prepared speech disappears and there are hints of genuine metanoia; 'Father, I have sinned against heaven and before you; I am no longer worthy to be called your son.' 
Elsewhere, I have discussed the relevance of evangelical repentance in the contemporary context - as witnessed, for example, in the interaction between Desmond Tutu and Winnie Mandela at the Truth and Reconciliation Commission in South Africa. Suffice it to say, the TRC itself and its widely recognised contribution to the peaceful transition from apartheid in South Africa is testimony to the socio-political significance of forgiveness and its capacity to generate metanoia. ${ }^{57}$ As Miroslav Volf argues so convincingly, far from undermining justice, 'every act of forgiveness enthrones justice....'58

In sum, evangelical repentance serves the law and the purposes of justice rather than undermining them. It does so by calling forth an attitude to God and to other that summarises the injunctions at the heart of the torah and 'images' or reflects God's righteous orientation toward humanity.

\section{Forgiveness and Semantic Externalism.}

The case with which we began, as also the case of Jill Saward, the victim in the Ealing Vicarage rape case, ${ }^{59}$ reflected the capacity of evangelical metanoia to generate actions that transcend what would normally be

\footnotetext{
57 See my essay in Philpott (ed), op cit.

58 Miroslav Volf, Exclusion and Embrace: A Theological Exploration of Identity, Otherness, and Reconciliation, (Nashville, Tennessee, Abingdon Press, 1996), p. 123.

59 While writing this paper, it was reported that Jill Saward had died of a stroke, aged 51. After the unthinkable violence that she and her family experienced in her home, she met and was reconciled with, the person primarily responsible for these horrendous acts. In a newspaper interview, she emphasises the contribution of her Christian faith: 'I don't think I'd be here today without my Christian faith. That's what got me through.' http://www.telegraph.co.uk/news/uknews/1512403/Its-notwhether-you-can-or-cant-forgive-its-whether-you-will-or-wont.html
} (accessed 5 January, 2017) 
considered normative, namely, what one could publically advocate that all people do in similar circumstances. ${ }^{60}$

Such cases raise questions about the way such people recognise and appropriate what they perceive to be the right action. What emerges is that, as Kierkegaard demonstrates so convincingly in Philosophical Fragments, the 'remembering' of God's purposes that stems from the incarnation is radically different from a Socratic remembering of what is right. The former is grounded in the recognition of God's particular, historical, redemptive engagement with humanity whereas the 'Socratic' involves making explicit what is universally immanent within the human mind - a form of remembering that might be occasioned by an historical event but for which no historical event can ever have 'decisive significance'.61 The implications are clear: without the recognition of historically enacted divine forgiveness, moral theology of this kind recognises no obligation to forgive.

Space does not allow us to investigate the semantic implications of this further. Suffice it to say, the significance of Jesus Christ for moral theology is not simply that he facilitates the articulation of moral obligations. Still further, the history of God's engagement with humanity defines the very

60 Cf Bernard Gert's Kantian definition of moral actions as what one could publically advocate that all people do in parallel circumstances. The Moral Rules: A New Rational Foundation for Morality, (New York, Harper and Row, 1970).

${ }^{61}$ An immanentist approach to moral theology would assume that we already know the content of morality and simply 're-cognise' what is already inherent in our minds. Kierkegaard exposed the incompatibility of this ('Socratic') approach with Christianity because, on such an account, no historical event or person can have 'decisive significance'. Edna $\mathrm{H}$. Hong \& Howard V. Hong (eds.) Johannes Climacus, Philosophical Fragments, (Princeton: Princeton University Press, 1985), chap 1. 
meaning of the relevant concepts. It is here we see the significance of a move made by Linda Zagzebski in Exemplarist Moral Theory. ${ }^{62}$ Zagzebski challenges the assumption that the fundamental conceptuality of moral action should be traced to ethical concepts whose meaning exists in our heads'. Zagzebski's approach to moral theory suggests we start not with moral concepts but with 'exemplars of moral goodness identified directly by the emotion of admiration.'

This approach makes most sense when it is interpreted in the light of a semantically externalist, as opposed to a descriptivist, account of the language of moral theology. An 'externalist' account understands its language as determined by means of its ability to track reality ${ }^{63}$ and, second, by 'a social linguistic network in which ordinary speakers defer to experts.'64 In Zagzebski's view, both aspects of such an account apply in Christian ethics central to which we find not a set of moral principles but Jesus Christ, Immanuel and a community whose life is constituted and defined by the confession 'Thou art the Christ, the Son of the Living God' that is, an indexical, 'second person' identification of the exemplar! What defines this gathered community is what Kierkegaard referred to as that 'kinship' which the eternal establishes with humanity in time 65 - a kinship that transforms our epistemic bases and thus every facet of our perception and orientation. What the Christian and thus the Christian ethicist remembers is that communion which God freely establishes with humanity in history. It is that same remembrance (anamnesis) that defines the 'sacrament of communion', therefore, that also defines the content of Christian moral theology. At the heart of both is what we might

62 Linda Zagzebski, Exemplarist Moral Theory, (Oxford, OUP, 2017).

63Zagzebski writes, 'The fact that we are thinking/talking about $\mathrm{H}_{2} \mathrm{O}$ when we think or say "water" is determined by the fact that water is $\mathrm{H}_{2} \mathrm{O}$, not by an idea in our minds.'

64 Zagzebski, pp. 13-14.

65 Søren Kierkegaard, Concluding Unscientific Postscript (Cambridge: Cambridge University Press, 2009), p. 480. 
call 'reconciled exemplarism', that is, forms of life where our perceptions of what is admirable are transformed such that we are given to share in 'that mind which was in Christ Jesus'. What distinguishes this from a more generic moral exemplarism, is that the function of this 'exemplar' does not lie in his exemplifying a set of moral ideals but, rather, in the fact that he mediates a relationship. The sole Mediator between God and humanity is a person and not a moral or legal system. The primary ministry of Jesus Christ is not to exemplify and remind us of ethical categories immanent within our minds (heads). Rather, it is to present God's redemptive love for an alienated humanity in such a way as to redeem our frames of reference, reconcile our orientation toward others and provide a language through which we might indwell God's world in new and properly functional ways.

I began by recounting the violent, racially motived murder of Anthony Walker and the commitment of his mother and sister to forgive those responsible. This counter-cultural commitment to forgive was seen to be a form of Christian 'remembering' - remembering that sustained an ongoing commitment to embody God's forgiveness of them which they witnessed in Jesus Christ and which invited them to do the same.

The purpose of this paper has been to explore the Biblical, theological, epistemic, and semantic warrant for an approach to Christian ethics that sees forgiveness as foundational. The account of moral theology that emerges cannot be translated into the terms of a 'natural law' ethic or even into a virtue ethic per se. What emerges is an ethic that lives from a remembering (anamnesis) of God's historical deliverance of his people. This remembering defines the torah and the identity of Israel.66 It also defines the sacraments and the anamnesis enacted through them. I have suggested that this remembering both holds forth and inspires that form of participation that defines the very essence of Christian existence. I have

66 Cf. Deuteronomy 11:18-21. 
sought to present this as a sui generis form of what might be termed 'reconciled exemplarism'.

In summary, the practices and forms of speech that reflected the Walkers' remembering of Jesus Christ exemplified the life of the new creation and God's capacity to bring reconciliation through it. The narrative of their act of forgiveness, as also that of Jill Saward, challenges moral theology to conceive its task in light of the One who has borne away our transgressions, separated our offenses from us and absorbed the full weight of their consequences. It also invites Christian ethics to define itself exclusively with recourse to 'that mind which was in Christ Jesus' recognised as the true 'image of the Father' and the inaugurator of God's Kingdom. When moral theology is conceived with recourse to the sole Mediator of God's purposes for humanity, its impetus, warrant and criterion are found to lie exclusively in that filial orientation that defines the life of the New Humanity. To that end, it also finds itself employing a language of obligation that tracks the rhemata (speech-acts) that he mediates. 


\title{
A.J. Torrance article
}

Key words.

Forgiveness, transformation, covenant, law, reconciliation, exemplarism, semantic externalism

\begin{abstract}
.
Acts of Christian forgiveness that run counter to natural inclinations and ethical intuitions raise questions about the nature of human identity and the basis of moral theology. An assessment of the biblical and theological warrant for Christian forgiveness challenges the ethical misappropriation of the language of covenant, torah and righteousness to that of contract, law and justice. This suggests that forgiveness should be seen as normative, indeed, obligatory rather than supererogatory. A theological account is then provided of the conditions under which our natural inclinations are transformed so as to facilitate an orientation of forgiveness. It is argued that the incarnation and participation in the mind of Christ where transformation is 'evangelical' and 'ecclesial' is axiomatic for the Christian life and thus moral theology. Consequently, the categories of moral theology reflect 'reconciled exemplarism' and also 'semantic externalism' - where its language tracks God's historical engagement with humanity rather than denotes immanent, ethical categories.
\end{abstract}

